\title{
Notes
}

\section{Private Abridgment of Speech and the State Constitutions}

Inexpensive and easily utilized channels of public communication are crucial to an effective system of freedom of expression. In recognition of this fact, the Supreme Court has held that the First Amendment bars governmental attempts to prohibit citizens from using publicly held public forums for expressive activity or from canvassing neighborhoods of private homes. Unfortunately, the effectiveness of these holdings is threatened by the displacement of traditional publicly held public forums by privately held ones, and the related growth of privately held multiple-housing-unit residential communities. The Supreme Court has held traditional First Amendment doctrine inapplicable in these new contexts because they involve private rather than governmental abridgment of speech.

This Note argues that the free speech guarantees contained in the fifty state constitutions are the appropriate vehicles for the protection of public forum and canvassing rights from private abridgment. These state constitutional provisions provide a right of access to privately held public forums for reasonable expressive activity and to privately held residential communities for reasonable canvassing. Protection of speech against private abridgment under these guarantees constitutes an important part of the trend away from exclusive reliance on the federal Constitution to protect civil liberties. ${ }^{1}$ This trend is already quite pronounced in the criminal procedure ${ }^{2}$ and equal protection $^{3}$ fields, and is becoming equally pronounced in the area of

1. For a useful, if dated, overview of developments in this area, see Project Report: Toward an Activist Role for State Bills of Rights, 8 HARv. C.R.-C.L. L. REv. 27 (1973) [hereinafter cited as Project Report].

2. See Wilkes, The New Federalism in Criminal Procedure Revisited, $64 \mathrm{Kr}$. L.J. 729 (1976); Wilkes, More on the New Federalism in Criminal Procedure, 63 KY. L.J. 873 (1975); Wilkes, The New Federalism in Criminal Procedure: State Court Evasion of the Burger Court, 62 Kx. L.J. 421 (1974).

3. Compare San Antonio Independent School Dist. v. Rodriguez, 411 U.S. 1 (1973) (education not fundamental interest under equal protection clause of federal Constitution) and Frontiero v. Richardson, 411 U.S. 677 (1973) (gender not suspect classification under 
free speech and its protection. ${ }^{4}$

The Note begins with an analysis of the impact of private abridgment on the expression system. It then discusses the role of the federal Constitution in the private abridgment context, and concludes by urging an expanded role for state constitutional guarantees of free speech in the protection of the public forum and canvassing components of the expression system.

\section{The Public Forum and Canvassing Components of the System of Freedom of Expression}

The right to use public forums for expressive activity and the right to canvass neighborhoods of private homes are essential components of the expression system. Effective exercise of these rights, however, is threatened by the recent rise of private abridgment of speech.

\section{A. The System of Freedom of Expression}

An effective expression system must insure that individuals and groups are afforded inexpensive and easily utilized channels of public communication. ${ }^{5}$ The Court, therefore, has held that the First Amendment protects from governmental abridgment expressive activity in publicly held public forums ${ }^{6}$ and canvassing of neighbor-

equal protection clause of federal Constitution) with Serrano v. Priest, 5 Cal. 3d 584, 487 P.2d 1241, 96 Cal. Rptr. 601 (1971) (education is fundamental interest under equal protection guarantee of California constitution) and Sail'er Inn v. Kirby, 5 Cal. 3d 1, 485 P.2d 529, 95 Cal. Rptr. 329 (1971) (gender suspect classification under equal protection guarantee of California constitution).

4. See, e.g., Burkoff \& Adamo, Obscenity Under the Michigan Constitution: Protected Expression? 54 MICH. ST. BaR J. 964 (1975); Note, Of Laboratories and Liberties: State Court Protection of Political and Civil Rights, 10 GA. L. REv. 533, 546-49 (1976).

5. See T. EMerson, The System of Freedom of Expression 286 (1970) (public assembly and petitioning are vital since they are only means through which radical, unpopular, or underprivileged individuals and groups can reach an audience).

6. The term "expressive activity" is used in this Note to denote direct communication in public to a mass audience or particular individuals. See id. The Supreme Court bcgan protecting expressive activity in streets, parks, and similar open, publicly owned spaces in Hague v. CIO, 307 U.S. 496, 515-16 (1939) (plurality opinion) ("The privilege of a citizen of the United States to use the streets and parks for communication of views . . must not, in the guise of regulation, be abridged or denied.") A majority of the Court adopted this approach in subsequent cases. See, e.g., Schneider v. State, 308 U.S. 147, 163 (1939); Cox v. New Hampshire, 312 U.S. 569, 574 (1941); Jamison v. Texas, 318 U.S. 413, 415-16 (1943). See also Food Employees Local 590 v. Logan Valley Plaza, Inc., 391 U.S. 308, 315 (1968) ("streets, sidewalks, parks, and other similar public places are so historically associated with the exercise of First Amendment rights that access to them for the purpose of exercising such rights cannot constitutionally be denied broadly and absolutely"). 
hoods of private homes. ${ }^{7}$ Courts have condemned governmental abridgment in these contexts because of the public ownership of streets, sidewalks, and parks. ${ }^{8}$ Protection of expressive activity therein is premised upon the importance of maintaining inexpensive communication channels, ${ }^{9}$ and the relative ease with which the problems generated by these communicative processes can be controlled. ${ }^{10}$

These twin First Amendment rights insure that individuals and groups seeking to communicate with the public have at their disposal two inexpensive, easily utilized, and effective channels of public communication: use of publicly held forum areas for expressive activity aimed at a mass audience, and canvassing of neighborhoods for communication with persons on an individual basis. Both techniques have been used for centuries by individuals and groups attempting to communicate ideas and information to the public. ${ }^{11}$

\section{B. Private Abridgment of Speech}

Unfortunately, the efficacy of these channels of communication is endangered by the modern trend toward private ownership of traditional public forums, and by the private ownership of residential communities. Because these entities are privately held, their owners have been held not subject to the requirements of the Court's First Amendment public forum and canvassing holdings. ${ }^{12}$

7. See Martin v. City of Struthers, 319 U.S. 141, 146-47 (1943) (holding municipal ordinance forbidding canvassing unconstitutional because of its importance to democratic political system); Hynes v. Mayor of Oradell, 425 U.S. 610 (1976) (striking down as unconstitutionally vague municipal ordinance requiring canvassers to register with local police department before canvassing).

8. See Hague v. CIO, 307 U.S. 496, 515 (1939) ("Wherever the title of streets and parks may rest, they have immemorially been held in trust for the use of the public and, time out of mind, have been used for purposes of assembly, communicating thoughts between citizens, and discussing public questions.")

9. See Martin v. City of Struthers, 319 U.S. 141, 146 (1943) ("[d]oor to door distribution of circulars is essential to the poorly financed causes of little people"). This statement is especially important in light of the Court's recent holdings that the First Amendment does not require licensed broadcasters to sell advertising time to individuals, see Columbia Broadcasting Sys., Inc. v. Democratic Nat'I Comm., 412 U.S. 94 (1973), and precludes a state from requiring newspapers to give reply space to attacked individuals, see Miami Herald Publishing Co. v. Tornillo, 418 U.S. 241 (1974).

10. See Martin v. City of Struthers, 319 U.S. 141, 146-47 (1943) (controlling dangers posed by door-to-door canvassing sufficiently easy so that stringent prohibition is "naked restriction of ideas"); Schneider v. State, 308 U.S. 147, 162 (1939) (controlling littering by prosecuting citizens who litter is better than proscribing handbilling).

11. Martin v. City of Struthers, 319 U.S. 141, 145-47 nn.6-9 (1943) (history of door-todoor canvassing); Schneider v. State, 308 U.S. 147, 164 (1939) (pamphlets have proven most effective in dissemination of opinion); Hague v. CIO, 307 U.S. 496, 515 (1939) (traditional use of streets and parks for assembly).

12. See p. 173 infra. 


\section{Privately Held Public Forums}

The most prominent example of this trend is the displacement as public gathering centers of publicly held downtown trading areas by privately held shopping centers. When the Court was developing its First Amendment public forum jurisprudence in the 1930s and 1940s, shopping centers were relatively few in number ${ }^{13}$ and traditional publicly held downtown trading districts served as the predominant public gathering centers for communities. By 1973, however, there were some 13,240 shopping centers in the United States. ${ }^{14}$ It is estimated that there will be approximately 25,000 shopping centers throughout the nation by $1985 .{ }^{15}$ In short, the privately held shopping center now serves as the public trading area for much of metropolitan America. ${ }^{16}$

Moreover, these shopping centers have increasingly assumed other functions traditionally associated with downtown business districts. Shopping centers often include banks, restaurants, discotheques, parking facilities, post offices, reference libraries, and even churches. Some also provide facilities for lectures and industrial conferences. ${ }^{17}$ Thus, shopping centers have become "new downtowns," in which members of the public may not only shop, but also stroll, sit, meet friends, and participate in community activities as they once did in downtown business districts. ${ }^{18}$ Indeed, many shopping center owners view this open posture toward the public as an essential element of shrewd business policy. ${ }^{19}$

13. Although the first shopping center was built in 1907 , as late as 1950 there were fewer than 100 shopping centers in the United States. Eagle, Shopping Center Control: The Developer Besieged, 51 J. URB. L. 585, 586, 589 (1974).

14. SHOPPING CENTER WORLd, Jan. 1973, at 27, 28-30.

15. PUblisher's WeEkLY, Feb. I, 1971, at 54.

16. The trading-area function is particularly important to the development of cities. See L. Mumford, The City IN History $410-45$ (1961). Interestingly, the shopping center, having established itself as the trading area for suburbia, is now returning to the downtown area from whose demise it originally profited. Business WEEK, Sept. 4, 1971, at 34. Thus, the traditional publicly held downtown trading area now faces competition not only from suburban shopping centers, but also nearby from privately held urban shopping centers.

17. N.Y. Times, Feb. 7, 1971, § 1, at 58, cols. 4-5.

18. See Breckenfeld, "Downtown" Has Fled to the Suburbs, Forrune, Oct. 1972, at 80; cf. Friedman, No, All Shopping Centers Are Not Alike, Los ANGeles, Nov. 1979, at 242 (describing public gathering-center functions of modern shopping centers).

19. The shopping center industry has often referred to shopping centers as "the new downtowns." SHOPpING CenTER WORLD, Feb. 1972, at 52. One owner enthusiastically noted that "by being good neighbors we can be more successful merchants." Morris, Shopping Centers: Main Street Moves to the Mall, MANagement Review, May 1969, at 48-49. To this end, care is taken to insure that the original design of the shopping center provides 
The implications of this development for those seeking an inexpensive channel of communication with a mass audience are clear. In many communities, shopping centers must be regarded as the most viable forum in which to communicate messages to the public.. ${ }^{20}$ Thus, use of shopping centers has become a standard campaign tactic. ${ }^{21}$ Unfortunately, many shopping center owners maintain a policy of excluding those who seek to engage in expressive activity on the premises. $^{22}$

\section{Privately Held Residential Communities}

A less prominent, but equally important, development is the growth of the privately held multiple-housing-unit residential community. Unlike private homes in a typical residential neighborhood setting, individual housing units ${ }^{23}$ are connected by privately held passageways-hallways, elevators, and stairwells within individual structures, and street-like pathways and roadways running between separate struc-

for public attraction areas such as malls and community centers. V. GRUEN \& L. SMirh, Shopping Towss U.S.A. 257 (1960). Additionally, shopping centers sponsor various nonretail promotions in order to attract people to the premises. See, e.g., Shopping CEnTER WorLd, Dec. 1972, at 17 (details of successful shopping center promotions).

20. A United States congressional candidate in a suburban district near Detroit noted the importance of shopping center campaigning: "Livonia [Michigan] typifies many of the difficulties of politics in the new suburbs. For a candidate, especially an insurgent with a limited local organization, suburbs like Livonia are virtually impregnable. There is no real center to it, only shopping centers. . ." Shapiro, One Who Lost, Wash. MonthLY, Dec. 1972, at 7,11 .

21. Id. Moreover, presidential candidates make a practice of campaigning in shopping centers. Breckenfeld, supra note 18, at 82 (noting shopping center campaigning by 1972 presidential candidates).

22. For example, when the Supreme Court held in Food Employees Local 590 v. Logan Valley Plaza, Inc., 391 U.S. 308 (1968), that the First Amendment required shopping center owners to allow labor picketing on the premises, many owners were "infuriated." Wall St. J., Feb. 20, 1969, at I, col. 6, 21, col. 1. When the Court held that the First Amendment did not require owners to allow political handbilling on the premises, see Lloyd Corp. v. Tanner, 407 U.S. 551 (1972), they were pleased that the Court had eliminated a "nuisance." Breckenfeld, supra note 18, at 156. Interestingly, some owners allow presidential candidates to use their facilities, but not political handbillers. See Lloyd Corp. v. Tanner, 407 U.S. 551, 555 (1972) (opinion of the Court); id. at 580 (Marshall, J., dissenting). Some owners, however, do believe that "[t]he public should be permitted into shopping centers for political purposes and political candidates should have the right to distribute handbills. . . . We have freedom of speech at stake here." SHopPING CenTER World, Aug. 1972, at 21, 22 (quoting Robert Bermant of National Shopping Centers).

23. The Bureau of the Census defines a housing unit as "a group of rooms or a single room occupied or intended for occupancy as separate living quarters, that is, the occupants do not live and eat with any other persons in the structure, and there is either (I) direct access from the outside or through a common hall, or (2) complete kitchen facilities for the exclusive use of the occupants." BUREAU of the CENSUS, U.S. Department OF CoMMerce, Statistical Abstract of the United States 1978, at 778 [hereinafter cited as 1978 STATistic.1L ABstract]. Owner-occupied homes and renter-occupied units are functionally indistinguishable under this definition. 
tures-rather than by publicly held streets and sidewalks. Examples of typical privately held residential communities are rental apartment complexes, ${ }^{24}$ mobile home parks, ${ }^{25}$ condominium complexes, ${ }^{26}$ and planned communities. ${ }^{27}$ This category also includes agricultural labor camps ${ }^{28}$ and nursing homes. ${ }^{29}$ Although these entities have not displaced private homes from the housing market, they do constitute over one-third of the occupied housing units in the United States.30 Moreover, in some areas they constitute a majority of the housing

24. An apartment complex is composed of multiple housing units, connected with each other by passageways inside a single structure. Some complexes contain multiple structures connected by privately held pathways. One study defines apartments as "units in structures containing three or more units." M. Neutze, The Suburban Apartarent Boom 11 (1968) (table).

25. A mobile home park is a plot of land upon which trailer-like mobile homes are parked. One study noted that a mobile home park "is in reality a subdivision of residential structures and nearly always of detached dwellings." 1 R. Newcomb, Mobile Home Parks 47 (1971) (Urban Land Inst., Tech. Bull. 66). In this sense, it is more like a neighborhood of private homes than an apartment complex. Unlike a neighborhood of private homes and like an apartment complex, however, "the park operator commonly retains ownership of the land surrounding and connecting the housing units." Id. at 48 .

26. Condominium complexes provide for "a system of separate ownership of individual units in multiple-unit buildings." 4B R. Powell, Real Property f 633.1, at 770 (1979). As with rental apartment complexes, the passageways connecting the individual units are privately held. Over four million Americans already live in some form of condominium unit, and one United States Department of Housing and Urban Development study predicts that half of the population will live in condominiums over the next 20 years. N.Y. Times, Nov, 24, 1977, $\$ \mathrm{C}$, at 14, cols. 1-6.

27. Planned communities are indistinguishable from typical residential neighborhoods, except for the fact that the streets within them are privately held and usually can be entered only through gatchouse entrances manned by guards. Some planned communities are surrounded all or in part by walls. See State v. Kolcz, 114 N.J. Super. 408, 409-10, 276 A.2d 595, 596 (Middlesex County Ct. 1971) (description of Rossmoor Community retirement village); Los Angeles Times, Jan. 13, 1980, § I, at 34, cols. 3-6 (advertisement for Leisure Village).

28. The modern-day agricultural labor camp includes, in addition to farmiand and agricultural facilities, housing facilities for migrant laborers resident on the premises. Many camp owners also provide sewage, garbage disposal, fire protection, and sometimes even minimal shopping facilities. See, e.g., Illinois Migrant Council v. Campbell Soup Co., 574 F.2d 374, 377-78 (7th Cir. 1978) (describing 201-acre mushroom farm known as Prince Crossing, Illinois).

29. As of 1974, there were over 16,500 nursing home facilities eligible for federal Medicare or Medicaid reimbursement, with a combined total of over one million residents. HeW, Public Health Service, Office of Nursing Home affairs, long-Tera Care FACILITY IMPROVEMENT StUdy, INTRODUCTORY REPORT 17-18 (1975). Unlike apartment complex residents, nursing home residents receiving custodial care do not generally reside in separate housing units. Like apartment dwellers, however, these individuals "reside in nursing homes owned by a private party and located on private property." See Comment, Nursing Home Access: Making the Patient Bill of Rights Work, 54 J. URB. L. 473, 493-94 (1977).

30. In the latest year for which statistics are available, 1976, renter-occupied units accounted for $35.3 \%$ of the occupied housing units in the United States. 1978 STATISTICAL Absrract, supra note 23, at 792 (Table No. 1377). Most renter-occupied housing units are in multiple-housing-unit structures. Moreover, many forms of owner-occupied housing structurally resemble renter-occupied housing. See notes 25-27 supra. 
units. ${ }^{31}$ This situation is unlikely to change in the near future. ${ }^{32}$

Although the owner of a privately held residential community is generally precluded from excluding a canvasser specifically invited by a tenant, ${ }^{33}$ the housing unit occupier must take the initiative in inviting the canvasser to his door to speak. By contrast, in a residential neighborhood with publicly held streets and sidewalks, the burden is on the housing unit occupier to exclude the canvasser by posting a "No Canvassing" warning. ${ }^{34}$ Moreover, in some circumstances exclusion of canvassers can give the owner control over the flow of information to persons resident on his property. Agricultural labor camp operators, for example, frequently exclude, among others, representatives of non-profit organizations that provide information and services to isolated migrant laborers. ${ }^{35}$ Similarly, nursing home operators frequently exclude representatives of non-profit organizations that monitor nursing home conditions. ${ }^{36}$

\section{The Federal Constitution, the States, and Private Abridgment of Speech}

The displacement of the publicly held downtown trading area by the suburban shopping center, together with the development of pri-

31. Eighty per cent of the 94,000 residents of Santa Monica, California, for example, are tenants. N.Y. Times, Apr. 12, 1979, $\$$ A, at 18, col. 6. When the 1970 Census was taken, a majority of the housing units in the District of Columbia, Hawaii, and New York were renter-occupied. 1978 Statistical ABstract, supra note 23, at 791 (Table No. 1376). Renter-occupied units comprised between $40 \%$ and $49.9 \%$ of the housing units in Alaska, California, Illinois, Maryland, Massachusetts, Nevada, and Rhode Island when the 1970 Census was taken. $I d$.

32. As the median price of a new home continues to rise, see N.Y. Times, Jan. 7, 1979, 12 (National Economic Survey), at 42, col. 1; Boston Globe, Jan. 12, 1980, at 14, col. 1, many families will be priced out of the private housing market and will have no choice but to rent. Moreover, much owner-occupied housing being developed structurally resembles renter-occupied housing. See p. 170 \& notes $25-27$ supra.

33. See Commonwealth v. Richardson, 313 Mass. 632, 48 N.E.2d 678 (1943) (tenants have easement over common passageways of apartment complex, thus preventing owner from excluding canvassers specifically invited by tenants).

34. See Martin v. City of Struthers, 319 U.S. 141, 148 (1943) (dictum) (municipality could punish only canvassers who called at homes in violation of warning posted by homeowner).

35. In the typical case, the camp operator denies a union organizer or representative of a public interest organization the right to communicate with the migrant workers on the camp premises. See Note, Access to Migrant Labor Camps: Marsh v. Alabama Revisited, 55 Ch.-KeNT L. Rev. 285, 292 \& n.45 (1979) (collecting cases).

36. Many nursing home patients are unable to journey beyond the confines of the nursing home. See Comment, supra note 29, at 473-74. In 1974 and 1976, the Department of Health, Education and Welfare promulgated regulations known as "patient bills of rights" that safeguard specific interests of nursing home patients. Id. at 474 . Officials of the Department have encouraged community groups to monitor nursing home activities in furtherance of this regulatory end. $I d$. at 479 . Nursing home operators have resisted such monitoring activities. $I d$. at 479 n.62 (collecting cases). 
vately held residential communities, indicates that changed socioeconomic circumstances have rendered the First Amendment public forum and canvassing doctrines inadequate to insure the availability of inexpensive and easily utilized vehicles of public communication. The Supreme Court has held that the First Amendment has no role to play in this area. Unless the goal of insuring the availability of these vehicles is to be abandoned, an alternative method of protecting these rights must be found. ${ }^{37}$

\section{A. The First Amendment and Private Abridgment of Speech}

One approach with many adherents would simply bring private abridgment of speech within the proscriptive ambit of the First Amendment through use of Fourteenth Amendment "state action" doctrine. ${ }^{38}$ Under this approach, the contemporary implications of private abridgment would be recognized by holding that the entities discussed in this Note either performed public functions ${ }^{39}$ or significantly involved the state in their abridgment through invocation

37. One often unnoticed virtue of these two First Amendment rights is that they give every person at least a toehold position in the marketplace of ideas, see $\mathrm{T}$. EMERson, supra note 5, without intruding upon the editorial autonomy goal of the system of freedom of expression, see Miami Herald Publishing Co. v. Tornillo, 418 U.S. 241 (1974) (state right of reply statute violates First Amendment by invading editorial autonomy). Such an intrusion would occur if, for example, licensed broadcasters were required to sell or even give away advertising time for messages. See Columbia Broadcasting Sys., Inc. v. Democratic Nat'l Comm., 412 U.S. 94, 126-27, 131 (1973) (leaving open possibility of governmental requirement of access to licensed broadcasters, despite effect on broadcasters' autonomy).

38. There is voluminous literature in this field arguing that abridgment by particular private entities constitutes "state action." See, e.g., Comment, The Public Forum from Marsh to Lloyd, 24 AM. U.L. REv. 159 (1974) (shopping centers); Note, Lloyd Corp. v. Tanner: The Demise of Logan Valley and the Disguise of Marsh, 61 Geo. L.J. 1187 (1973) (shopping centers); Cases Noted, 48 CoLum. L. REv. 1105 (1948) (apartment complexes); Comment, supra note 29 (nursing homes); Sherman \& Levy, Free Access to Migrant Labor Camps, 57 A.B.A.J. 434 (1971) (agricultural labor camps); Note, supra note 35 (agricultural labor camps); Note, First Amendment and the Problem of Access to Migrant Labor Camps After Lloyd Corporation v. Tanner, 61 CoRNeLL L. REv. 560 (1976) (agricultural labor camps).

39. The "public function" strand of state action analysis originated in Marsh v. Alabama, 326 U.S. 501 (1946), in which the Court held that a privately owned municipality was precluded by the First Amendment from curtailing religious handbilling on the sidewalks of its downtown trading area. Because the town had "all the characteristics of any other American town," $i d$. at 502, its actions were treated as governmental even though it was wholly owned by a private corporation, id. at 508. Marsh thus insures that states may not delegate governmental functions to private parties in order to escape federal constitutional obligations. See The Supreme Court, 1974 Term, 89 HARv. L. REv. 47,144 (1975). However, the Marsh public function doctrine has been carefully confined to functions exclusively performed by state governments. See Flagg Bros. v. Brooks, 436 U.S. 149, 159-63 (1978). 
of state trespass statutes. ${ }^{40}$ At one time, it appeared that this approach might protect public forum and canvassing rights from private abridgment. ${ }^{41}$

This development did not materialize. Because the Court has found governmental action not to be present in the exclusion of expressive activity by owners of these properties, ${ }^{42}$ First Amendment public forum and canvassing rights are inapplicable to a significant number of areas that attract persons interested in exercising them. Thus,

40. The "significant state involvement" strand of state action analysis originated in Shelley v. Kraemer, 334 U.S. 1 (1948), in which the Court held that judicial enforcement of racially restrictive covenants constituted state action sufficient to invoke the equal protection clause of the Fourteenth Amendment. But cf. Flagg Bros. v. Brooks, 436 U.S. 149 , 164-66 (1978) (invocation of state statute by warehouseman in order to sell goods cntrusted to him for storage not state action); Jackson v. Metropolitan Edison Co., 419 U.S. 345, 358 (1974) (Shelley doctrine limited to situations in which state had fostered or encouraged conduct at issue). Each shopping center case decided by the Supreme Court involved the use of trespass or similar statutes to prevent expressive activity on the premises. See Hudgens v. NLRB, 424 U.S. 507, 508 (1976); Lloyd Corp. v. Tanner, 407 U.S. 551,556 (1972); Food Employees Local 590 v. Logan Valley Plaza, Inc., 391 U.S. 308, 311-12 (1968). For an argument that invocation of trespass statutes can amount to state action, see Abernathy, Expansion of the State Action Concept Under the Fourteenth Amendment, 43 CoRneli. L.Q. 375, 412 (1958).

41. First Amendment protection of expressive activity on private property began in Marsh v. Alabama, 326 U.S. 501 (1946), in which the Court held that a privately held municipality could not abridge handbilling on its "business block," because the municipality performed a "public function." Id. at 502-03, 506. Its actions were thus treated as governmental even though title to the property at issue was exclusively in the hands of a private corporation. In Food Employees Local 590 v. Logan Valley Plaza, Inc., 391 U.S. 308 (1968), the Court held that the First Amendment protected peaceful picketing within the confines of a privately held shopping center "in a manner and for a purpose generally consonant with the use to which the property is actually put." $I d$. at 319-20. It analogized the modern shopping center to the "business block" in Marsh. Id. at 317 . The Logan Valley analysis extended the First Amendment well beyond the Marsh "company town" context to encompass all privately held areas that, in practice, function as public gathering places or thoroughfares. See T. EMErson, supra note 5, at 309 . It also furnished the basis for opening privately held residential communities to canvassers. $I d$.

42. In Lloyd Corp. v. Tanner, 407 U.S. 551 (1972), the Court rejected the application of the First Amendment to political handbilling in a private shopping center when the handbilling was unrelated to the commercial functions of the shopping center property. Lloyd distinguished Logan Valley on two grounds. First, the expressive activity in Logan I'allcy was directed to the labor relations policies of a shopping center tenant, 391 U.S. at $311-12$, whereas the expressive activity in Lloyd was directed to U.S. Vietnam War policies, 407 U.S. at 556, 564-66. Second, the political handbillers in Lloyd, unlike the labor pickets in Logan I'alley, had available adequate alternative avenues of communication with shopping center patrons. 407 U.S. at 566-67. In dictum, the Lloyd Court expressly rejected the Logan Valley application of the First Amendment to private abridgment of speech. 407 U.S. 551, 567 (First and Fourteenth Amendments safeguard rights of free specch by limitations on state action rather than action of private property owners). Four years later, in Hudgens v. NLRB, 424 U.S. 507 (1976), the Court explicitly recognized that Lloyd had overruled Logan Valley. Id. at 518 (rationale of Logan Valley did not survive Lloyd). Accordingly, it withdrew from the private abridgment field with the statement that "the constitutional guarantee of free expression has no part to play" in this context. Id. at 521. Although Marsh is still good law, 424 U.S. at 513-14, the Court probably has confined it exclusively to its facts. 
this approach will not protect those rights from private abridgment.

It is clear that considerations of federalism as well as those of constitutional interpretation have dictated the Court's withdrawal from the private abridgment field. The Court has determined that abridgment of speech by these entities, along with the interests of persons in engaging in expressive activity on their properties, is merely a part of the private ordering of property relationships in the non-governmental world. ${ }^{43}$ These relationships have traditionally been defined exclusively by state law, ${ }^{44}$ and a federal judicial finding of state action in these circumstances would intrude upon statedefined property relationships in order to protect a speech interest not found in the First Amendment.45

\section{B. The States and Private Abridgment of Speech}

As the Court withdrew from the private abridgment field, it suggested that state governmental institutions fill the gap. ${ }^{40}$ It explicitly left states the option of prohibiting owners of private property that functionally replicates either traditional public forums or public streets from excluding persons who wish to engage in reasonably exercised expressive activity. Although the First Amendment does not encompass this policy, the logic of the Court's withdrawal suggests that states should adopt it. The First Amendment, like all provisions of the Bill of Rights, merely sets minimum federal standards, and does not preclude states from providing greater protection to expressive activity within their borders. ${ }^{47}$

43. Compare Flagg Bros. v. Brooks, 436 U.S. 149, 157-60 (1978) (resolution of private civil disputes not an exclusive function of the sovereign, thus warehouseman's proposed sale of goods entrusted to him for storage under provisions of state statute not state action) with Marsh v. Alabama, 326 U.S. 501 (1946) (municipal government an exclusive function of the sovereign, thus actions of privately held municipality treated as governmental).

44. See Board of Regents v. Roth, 408 U.S. 564, 577 (1972).

45. See Lloyd Corp. v. Tanner, 407 U.S. 551, 567 (1972) (“II]t must be remembercd that the First and Fourteenth Amendments safeguard the rights of free speech and assembly by limitations on state action, not on action by the owner of private property used nondiscriminatorily for private purposes only.")

46. See Hudgens v. NLRB, 424 U.S. 507, 513 (1976) ("while statutory or common law may in some situations extend protection or provide redress against a private corporation or person who seeks to abridge the free expression of others, no such protection or xedress is provided by the Constitution itself").

47. See Brennan, State Constitutions and the Protection of Individual Rights, $90 \mathrm{HARv}$. L. REv. 489, 489-95, 498-502 (1977). The Court has recognized this point in several recent cases. See, e.g., Paris Adult Theatre I v. Slaton, 413 U.S. 49, 64 (1973) (although obscenity unprotected under First Amendment, states free to drop legal controls on obscenity); Cooper v. California, 386 U.S. 58, 62 (1967) (states free to impose higher standards on searches and seizures than required by Fourth Amendment). 
Moreover, states adopting this policy would not run afoul of any federal constitutional guarantees accorded property owners. First, the property owner cannot successfully raise a substantive due process objection, because this policy would clearly be founded upon a rational basis. ${ }^{48}$ Second, the state prohibition of private abridgment would not amount to a "taking" requiring just compensation of the owner under the Fifth and Fourteenth Amendments. ${ }^{49}$

To be sure, such a policy would prevent the property owner from excluding unwanted.persons under certain circumstances. ${ }^{50}$ The right to exclude others is undoubtedly a fundamental element of any property right. ${ }^{51}$ However, it is merely one element of a bundle of property interests, and it is settled doctrine that state action that merely deprives an owner of one element of such a bundle does not

48. See Ferguson v. Skrupa, 372 U.S. 726 (1963). In Robins v. Pruneyard Shopping Center, 23 Cal. 3d 899, 592 P.2d 341, 153 Cal. Rptr. 854 (1979), aff'd sub nom. PruneYard Shopping Center v. Robins, 100 S. Ct. 2035 (1980), the California Supreme Court based its adoption of this policy on the public forum role profitably assumed by shopping centers in California, and the need not only to protect general speech rights, but also the signature-gathering elements of the related California constitutional rights of initiative, referendum, recall, and general petitioning. $I d$. at 907-08, 592 P.2d at 345,153 Cal. Rptr. at 858. It analogized protection of speech and petitioning to valid health, safety, and environmental regulations. Id. at 908, 592 P.2d at 346, 153 Cal. Rptr. at 859.

49. U.S. Const. amend. $V$ provides, in relevant part, that "private property [shall not] be taken for public use, without just compensation." U.S. CoNST. amend. XIV provides, in relevant part, that no state shall "deprive any person of life, liberty, or property, without due process of law." The takings clause of the Fifth Amendment was incorporated into the Fourteenth Amendment due process guarantee in Chicago, B. S. Q. R.R. v. Chicago, 166 U.S. 226, 241 (1897). One court has held that these provisions prevent a state from prohibiting private abridgment of speech. In Lenrich Assoc. v. Heyda, 264 Or. 122, 504 P.2d 112 (1972), the court found that it was prevented from holding that the free speech guarantee of the state constitution protected expressive activity in a privately held shopping center. Id. at 127-29, 504 P.2d at 115-16 (plurality opinion). Lenrich is premised upon dicta in Lloyd Corp. v. Tanner, 407 U.S. 551 (1972), concerning the property rights of a shopping center owner. See id. at 552-53 (certiorari granted to consider owner's contention that lower court decision holding that First Amendment protected political handbilling on shopping center premises violates property owner's Fifth and Fourteenth Amendment property rights); $i d$. at 570 (Fifth and Fourteenth Amendment property rights, as well as First Amendment rights, must be respected and protected). But Lloyd ultimately held that "there has been no such dedication of Lloyd's privately owned and operated shopping center to public use as to entitle respondents to exercise therein the asserted First Amendment rights." Id. This holding did not create any federal property right of shopping center owners to exclude from their property persons wishing to engage in expressive activity therein.

50. See Kaiser Aetna v. United States, 444 U.S. 164, 178-80 (1979) (takings clause prevents federal government from using navigational servitude power to create public right of accoss to former inland pond that private developers had opened to ocean for use as marina by fee-paying customers without paying just compensation, because such right sovernment sought to create would take away owner's right to exclude unwanted users of pond).

51. See $i d$. at 179.80 ("right to exclude" universally held to be fundamental element of property right). 
amount to a taking. ${ }^{52}$ This is because judicial attention is inevitably focused on the impact of a particular governmental policy on an owner's aggregate of property interests. ${ }^{53}$

This approach was the one taken by a unanimous Supreme Court in upholding the adoption by California of the policy urged herein against a "takings" challenge mounted by a shopping center owner. ${ }^{54}$ The Court upheld this policy on the ground that it did not significantly impair the commercial value or use of the property. ${ }^{55}$ Indeed, it is quite analogous to valid federal and state labor legislation requiring property owners to permit union expressive activities on their property, ${ }^{56}$ and does not result in a "taking" requiring compensation. ${ }^{57}$

Finally, a state policy protecting speech against private abridg-

52. See Andrus v. Allard, 444 U.S. 51, 65-66 (1979) ("[T]he denial of one traditional property right does not always amount to a taking. At least where an owner possesses a full 'bundle' of property rights, the destruction of one 'strand' of the bundle is not a taking, because the aggregate must be viewed in its entirety.")

53. Id.; cf. Armstrong v. United States, 364 U.S. 40, 48 (1960) ("not every destruction or injury to property by governmental action has been held to be a 'taking' in the constitutional sense").

54. PruneYard Shopping Center v. Robins, 100 S. Ct. 2035 (1980).

55. Id. at 2042 ("There is nothing to suggest that preventing appellants from prohibiting this sort of activity will unreasonably impair the value or use of their property as a shopping center.")

56. See Eastex, Inc. v. NLRB, 437 U.S. 556, 563-76 (1978) (National Labor Relations Act protects employee distribution on company property of union publication substantially devoted to nonorganizational political commentary); Agricultural Labor Relations Bd. v. Superior Court, 16 Cal. 3d 392, 411-19, 546 P.2d 687, 699-705, 128 Cal. Rptr. 183, 195-201, appeal dismissed sub nom. Kubo v. Agricultural Labor Relations Bd., 429 U.S. 802 (1976) (California Agricultural Labor Relations Act requires farmers to grant nonemployee union organizers access to their property for communication with employees); cf. Heart of Atlanta Motel v. United States, 379 U.S. 241, 258-61 (1964) (prohibition of racial exclusion by owners of public accommodations not a taking); id. at 277-78 (Black, J., concurring) (Civil Rights Act of 1964 does not even come close to taking).

57. Nor would it infringe upon any First Amendment right of property owners to exclude speech activities from their property. This right was asserted by the shopping center owner in PruneYard Shopping Center v. Robins, 100 S. Ct. 2035, 2043-44 (1980). It was premised upon a line of Court decisions holding that the First Amendment prohibits governments from compelling individuals to convey messages. See Wooley v. Maynard, 430 U.S. 705, $714-17$ (1977); Miami Herald Publishing Co. v. Tornillo, 418 U.S. 241, 247-58 (1974); West Va. Bd. of Educ. v. Barnette, 319 U.S. 624, 630-42 (1943). The Court rejected application of these holdings as inapposite in a situation where the state was merely preventing an owner from excluding individuals who wish to communicate with those on his property rather than forcing him to convey a state-sponsored message. See PruneYard Shopping Center v. Robins, 100 S. Ct. 2035, 2044 (1980). The situation presented by state adoption of the policy urged herein is more analogous to that in Hudgens v. NLRB, 424 U.S. 507 (1976), in which the Court made it clear that the National Labor Relations Act could constitutionally prevent the owner from abridging labor picketing. Id. at 521-23. On remand, the NLRB held that federal labor law compelled such a result. Scott Hudgens, 230 N.L.R.B. 414 (1977). This result, of course, is quite incompatible with any asserted First Amendment right of property owners to exclude individuals who wish to engage in expressive activity on the property. 
ment is constitutionally supported by the Court's series of holdings that property rights are not created by the Constitution and exist exclusively under state law. ${ }^{58}$ Thus, while the First Amendment does not recognize a person's interest in protection against purely private abridgment of speech, the Fifth Amendment at the same time does not absolutely protect a private abridger of speech from state protection of reasonably exercised expressive activity on his property. The Court's withdrawal from the private abridgment field leaves the matter entirely in the hands of the states.

\section{The State Constitutions and Private Abridgment of Speech}

The considerations of federalism that have dictated the Court's withdrawal from the private abridgment field, together with the contemporary impact of private abridgment on the expression system, ${ }^{59}$ dictate that the states enter and protect persons against private abridgment. This could be accomplished through injunctive relief that prevents private owners of public forums and residential communities from excluding persons who engage in reasonably exercised expressive activity.

\section{A. Sources of State Protection Against Private Abridgment}

There are three possible sources of state protection against private abridgment of speech: statutory law, ${ }^{60}$ common law, ${ }^{61}$ and state

58. Sce Board of Regents v. Roth, 408 U.S. 564, 577 (1972) (property rights are not created by Constitution but by independent sources such as state law); cf. Paul v. Davis, 424 U.S. 693, 712 (1976) (interest in reputation "is simply one of a number [of interests] which the State may protect against injury by virtue of its tort law"); Bishop v. Wood, 426 U.S. 341,344 (1976) ("A property interest in employment . . . must be decided by reference to state law.")

59. See pp. 165-71 supra.

60. A few states have enacted legislation that prevents owners of certain types of property from excluding those who wish to exercise rights of expression on the premises. See, e.g., MrNn. STat. ANN. \$210A.43 (West Supp. 1979) (unlawful "for any person, either directly or indirectly, to deny access to any apartment house, dormitory, nursing home, mobile home park, any areas in which two or more single family dwellings are located on private roadways or other multiple unit facility used as a residence, to any candidate who has filed for election to public office or workers accompanied by the candidate . . ."); cf. CiL. LiBor CODE $\$ 1152$ (West Supp. 1979) (limited right of access to agricultural property granted to union organizers); Cal. Dep'x of General Services, 8 Cal. Adm. Code $\$ \$$ 20900-20901 (I976) (same). An administrative regulation of the Pennsylvania Department of Public Welfare grants outsiders the right to enter nursing homes. Brown, An Appraisal of the Nursing Home Enforcement Process, 17 ARIz. L. REv. 304, 318 n.121 (1975) (citing 4 Health Liw Project, U. Pa. Law School, Materials on Nursing Homes 185-88 (rev. ed. 1972)). The California Legislature, however, refused to enact legislation requiring owners of shopping centers to permit signature gathering and voter registration on the premises. See Cal. Assembly Bill No. 649, 1977-78 Regular Session; CaL. Legis., 1977-1978 Regular Session, Assembly final History, vol. 1, at 461.

61. Sce, e.g., State v. Shack, 58 N.J. 297, 277 A.2d 369 (1971) (under New Jersey law 
constitutional law. Only the third, however, would effectively protect vital public forum and canvassing rights from private abridgment.

An important feature of an effective system of freedom of expression is its reliance on independent judicial institutions, rather than elective political ones, such as legislatures, to supervise the functioning, as opposed to the outcomes, of democratic process. ${ }^{62}$ Courts, rather than legislatures, are relied upon to safeguard democratic process from governmental abridgment of speech. Similarly, courts should be relied upon to protect the democratic process from private abridgment. Unlike reliance on statutory or common law, use of state constitutional law would ensure effective judicial protection of access to privately held public forums and residential communities..$^{03}$

\section{B. Free Speech Guarantees in State Constitutions}

Every state constitution contains a free speech guarantee, but few state courts have critically analyzed the meaning of these guarantees. ${ }^{64}$ Although the First Amendment sets minimum federal speechprotection standards, it does not prevent state courts from providing greater speech protection under analogous guarantees in state constitutions. ${ }^{65}$ Moreover, the language and history of the state con-

ownership of real property does not include right to bar access to governmental services available to migrant workers resident on owner's property); Freedman v. New Jersey State Police, 135 N.J. Super. 297, 343 A.2d 148 (1975) (Shack access right to agricultural labor camps extended to members of press); cf. State v. Korich, 219 Minn. 268, 17 N.W.2d 497 (1945) (quiet and orderly canvassing in apartment complex upheld against charge of disorderly conduct brought by owner). A tort law solution is proposed in Schwartz, $A$ Landholder's Right to Possession of Property V'ersus A Citizen's Right of Free Speech: Tort Law As A Resource For Conflict Resolution, 45 U. CiN. L. REv. 1 (1976).

62. See T. Emerson, supra note 5, at 13 ("[T] he judicial institutions . . . here deal essentially with the methods of conducting the democratic process, not with the substantive results of that process. In this differentiation of function lies a generic distinction between the role of the judiciary and the role of the legislature.")

63. Although the common law approach, see note 61 supra, initially achievcs judicial protection of speech, it leaves the legislature the option to nullify the judicial initiative with new statutory law. This commonly occurs in state tort law. See, e.g., Evans v. Board of County Comm'rs, 174 Colo. 97, 105, 482 P.2d 968, 972 (1971) (overturning doctrinc of sovereign immunity from tort liability with statement that legislature was free to restore this doctrine if it chose to do so).

64. Most courts have simply assumed that the state guarantee was to be construed in pari materia with the First Amendment. See, e.g., Freedman v. State, 233 Md. 498, 505, 197 A.2d 232, 235-36 (1964), rev'd on other grounds, 380 U.S. 51 (1965); cf. Sigma Delta Chi v. Speaker, 270 Md. I, 310 A.2d 156 (1973) (freedom protected is substantially same as that protected by First Amendment). Thus, it is not surprising that commentators have generally ignored state constitutional guarantees of free speech. For example, none of the articles listed in note 38 , supra, discuss these provisions. Indeed, there is only one article devoted exclusively to state constitutional guarantees of free speech. See Note, Freedom of Expression Under State Constitutions, 20 STAN. L. REv. 318 (1968) (discussing only governmental abridgment of speech).

65. See note 47 supra. 
stitutional guarantees of free speech and related rights of expression ${ }^{66}$ indicate that they provide protection for public forum and canvassing rights against private abridgment.

\section{Affirmative Free Speech Rights in State Constitutions}

The issues of private abridgment involves the relationship of property rights of landowners with the public's interest in free speech. The states, as regulators of property rights, ${ }^{67}$ are the best arbiters of any resulting conflicts. The free speech guarantees in forty-four state constitutions create an affirmative right of free speech, unlike the mere limitation on state action found in the First Amendment. ${ }^{88}$

The text of the California guarantee is typical: "Every person may freely speak, write, and publish his or her sentiments on all subjects, being responsible for the abuse of that right. A law may not restrain or abridge liberty of speech or press." ${ }^{69}$ Although the legislative history of the California free speech guarantee is silent as to whether its framers intended to reach private abridgment, there can be little doubt that they drafted a guarantee more protective than the First Amendment. ${ }^{70}$

The California Supreme Court recognized this when it held in Robins v. Pruneyard Shopping Center ${ }^{71}$ that this provision, along

66. Many states also protect the related rights of assembly and petition. See, e.g., C.1. Const. art. I, \$ 3; Mích. Consr. art. I, \$3. Many also provide for citizen-initiated legislation through guarantees of initiative and referendum. See, e.g., CAL. Coxsr. art. II, $\$ \$ 8-11$; Wish. CoNsT. art. II, $\$ 1$. These provisions require proposals to be accompanied by a minimum number of signatures in order to qualify for the ballot. $I d$. They therefore provide additional constitutional support for state protection of exercise of public forum rights in privately held properties that practically function as public forums.

67. Sce pp. 174, 177 supra.

68. See Hudgens v. NLRB, 424 U.S. 507, 513 (1976) ("It is, of course, a commonplace that the constitutional guarantee of free speech is a guarantee only against abridgment by government . . . .")

69. Cist. Const. art. I, $\S 2$.

70. The California free speech guarantee was taken from the Iowa Constitution of 1846 and placed in the first California Constitution in 1849 without debate, and has not been significantly addressed since. Under this provision, persons in California may speak, write, and publish freely on all subjects, subject to liability only for abuse of this affirmative right. Moreover, the latter limitation refers only to liability for defamation, and is not intended to limit the scope of the affirmative speech right. Finally, the second sentence of the California guarantee, see $i d$., provides additional protection against governmental abridgment. See Note, Rediscovering the California Declaration of Rights, 26 Hisrings L.J. 481, 491-96 (1974). The framers of the similarly worded Michigan free speech guarantee, drafted in 1961, explicitly stated their intention to protect speech independently of the First Amendment. See Norris, A "Freedom of Expression" in the New Constitution, 31 DET. LAw. 190, 190-91 (1963).

71. 23 Cal. $3 d$ 899, 592 P.2d 341, 153 Cal. Rptr. 854 (1979), aff'd sub nom. PruneYard Shopping Center v. Robins, $100 \mathrm{~S}$. Ct. 2035 (1980). 
with related constitutional guarantees, ${ }^{72}$ protected expressive activity $^{73}$ in a privately owned shopping center. ${ }^{7 *}$ The court held that the property owner could subject the expressive activity only to reasonable regulation, and would be constitutionally enjoined from excluding it altogether. ${ }^{75}$ This holding was premised entirely upon the public forum role assumed by shopping centers in California ${ }^{73}$ and not on any finding of state action behind the owner's abridgment of speech. ${ }^{i 7}$ The Pruneyard court viewed the broader coverage of the state guarantee, together with the contemporary impact of shopping centers on the California political process, as sufficient to reach private abridgment in this context. ${ }^{78}$

The free speech guarantees in forty-three other state constitutions are linguistically similar to the California guarantee, notably in their provision of an affirmative right rather than simply a restraint on state action. ${ }^{79}$ Although some courts in those states have evaded the

72. The court also rested its holding on the California constitutional guarantecs of initiative, referendum, recall, and general petitioning. 23 Cal. 3d at 907-08, 592 P.2d at 345, 153 Cal. Rptr. at 858.

73. Appellants before the California Supreme Court in the case were high school students who set up a cardtable in the central courtyard of a shopping center to solicit signatures on a petition expressing opposition to a United Nations resolution labeling Zionism as a form of racism. Id. at 902, $592 \mathrm{P} .2 \mathrm{~d}$ at $342,153 \mathrm{Cal}$. Rptr. at 855.

74. PruneYard Shopping Center is a privately owned, 2l-acre suburban shopping center with 65 shops, 10 restaurants, and a cinema, as well as parking areas, walkways, and plazas. $I d$.

75. Id. at 902, 911, 592 P.2d at 342, 347-48, 153 Cal. Rptr. at 855, 860.61. The trial court in Lenrich Assoc. v. Heyda, Civil No. $373-433$ (Cir. Ct. MIultnomah County, Or., Mar. 23, 1972), rev'd, 264 Or. 122, 504 P.2d 112 (1972), issued a similar injunction. See Recent Cases, 86 HARv. L. REv. 1592, 1593 n.2 (1973).

76. The court cited statistical evidence of the decline in retail sales activity in downtown trading districts, together with the rapid growth in shopping center retail sales, to "dramatize the potential impact of the public forums sought here." $23 \mathrm{Cal}$. 3d at 907, 592 P.2d at 345, 153 Cal. Rptr. at 858. It concluded by noting that thousands of persons "[a]s a result of advertising and the lure of a congenial environment . . . are induced to congregate daily to take advantage of the numerous amenities offered by the ... [shop. ping center]." Id. at 910-11, 592 P.2d at 347, 153 Cal. Rptr, at 860 .

77. Rather, the court simply noted that "the public interest in peaceful speech outweighs the desire of property owners for control over their property." Id. at 909,592 P.2d at 347,153 Cal. Rptr. at 860.

78. The court, after quoting the language of the state free speech guarantec, noted that "[ $t]$ hough the framers [of the California guarantee] could have adopted the words of the federal Bill of Rights they chose not to do so. . . . Special protections thus accorded speech are marked in this court's opinions. Wilson v. Superior Cottrt (1975) 13 Cal. 3d 652, 658, 119 Cal. Rptr. 468, 472, 532 P.2d 116, 120, for instance noted that '[a] protective provision more definitive and inclusive than the First Amendment is the right of free speech and press.' "Id. at 908, 592 P.2d at 346, 153 Cal. Rptr. at 859.

79. See Ala. Const. art. I, $\S 4$; AlasKa Const. art. I, $\S 5$; Ariz. Const. art. II, $\$ 6$; ARK. Const. art. II, $\$ 6$; Colo. Const. art. II, $\$ 10$; Conn. Const. art. I, $\$ 4$; FlA. Const. art. I, \$4; GA. Cosist. art. I, $\$ 1$, para. 4; IDAho Const. art. I, \$9; ILL. Const. art. I, \$4; Iowa Const. art. I, § 7; KAN. BILL of RIGHTs, § 1I; KY. BILL OF RIGHTS, § 8; LA. CoNST. art. I, $\S 7$; ME. Const. art. I, $\S 4$; MD. DeCL. of Rights, art. 40; MASS. Const. art. 77; 


\section{Private Abridgment}

private abridgment issue by assuming uncritically that the state guarantee at issue must be construed in pari materia with the First Amendment, ${ }^{80}$ a few have used state guarantees to reach private abridgment of speech. For example, in Freedman v. New Jersey State Police, $^{81}$ the New Jersey Superior Court held that since the free speech guarantee of the New Jersey Constitution was linguistically broader than the First Amendment, ${ }^{82}$ the owner of an agricultural labor camp would be prohibited from excluding members of the press who wished to communicate with workers residing on his property. ${ }^{83}$ Similarly, when an evenly divided Michigan Supreme Court upheld handbilling in shopping centers in Amalgamated Clothing Workers v. Wonderland Shopping Center, Inc., ${ }^{84}$ the four justices who voted in favor of expressive activity on the premises based their holding partially on the linguistically broader free speech guarantee in the state constitution. ${ }^{85}$ Finally, the Washington Court of

Mich. Const. art. I, § 5; MInN. Const. art. I, § 3; Miss. Const. art. III, § 13; Mo. Const. art. I, § 8; Mont. Const. art. II, § 7; Neb. Const. art. I, § 5; Nev. ConsT. art. I, § 9; N.H. Const. Part I, art. 22d; N.J. Const. art. I, $\$ 6 ;$ N.M. Const. art. II, $\S 17 ;$ N.Y. Const. art. I, § 8; N.C. Const. art. I, § 14; N.D. Const. art. I, § 9; OHIo Const. art. I, § 11; OkIA. Const. art. II, \$ 22; PA. Const. art. I, § 7; R.I. Const. art. I, § 20; S.D. Const. art. VI, $\S$ 5; Tenn. Const. art. I, $\$ 19$; Tex. Const. art. I, $\$ 8$; Vt. Const. ch. I, art. 13; Wash. Const. art. I, $\S 5$; Wis. Const. art. I, $\S 3$; Wyo. Const. art. I, $\S 20 ; c f$. Del. Const. art. I, $\$ 5$. Although the text of the Delaware provision protects only press freedom, the Delaware courts have construed it to protect speech as well. See State v. Ceci, 255 A.2d 700 (Del. Super. Ct. 1969).

80. Thus, the highest courts of New York and Virginia have upheld the exclusion of canvassers from apartment complexes on the grounds that governmental abridgment was not present in this context. See Watchtower Bible \& Tract Soc'y v. Metropolitan Life Ins. Co., 297 N.Y. 339, 79 N.E.2d 433, cert. denied, 335 U.S. 886 (1948); Hall v. Commonwealth, 188 Va. 72, 49 S.E.2d 369, appeal dismissed, 335 U.S. 875 (1948). Although plaintiffs raised the state guarantees as an issue in each case, see Watchtower Bible \& Tract Soc'y v. Metropolitan Life Ins. Co., 297 N.Y. at 345, 79 N.E.2d at 435; Hall v. Commonwealth, 188 Va. at 73,49 S.E.2d at 370 , neither court attempted to construe them independently of the First Amendment. Had they done so, they might have seen the real issue present in both cases: erosion of the canvassing right through private ownership of passageways connecting multiple housing units. Cf. State v. Martin, 199 La. 39, 5 So. 2d 377 (1941) (upholding exclusion of canvasser by plantation owner). In a recent libel case, however, the Louisiana Supreme Court stated in dictum that it could protect speech independently of the First Amendment. Mashburn v. Collin, 355 So. 2d 879, $891-92$ (La. 1977).

81. 135 N.J. Super. 297, 343 A.2d 148 (1975).

82. The court initially invoked State v. Shack, 58 N.J. 297,277 A.2d 369 (1971). 135 N.J. Super. at 299,343 A.2d at 150 . It then extended the Shack access right to members of the press on the basis of its interpretation of Art. I, $\$ 6$ of the New Jersey Constitution. Id. at $301,343 \mathrm{~A} .2 \mathrm{~d}$ at $15 \mathrm{~L}$. In doing so, it referred to the provisions of the New Jersey Constitution's declaration of rights, including presumably the free speecl guarantee, as "provid[ing] greater protection to individual rights and liberties than the federal [Constitution]." Id. at 300,343 A.2d at 150.

83. 135 N.J. Super. at 301,343 A.2d at 151.

84. 370 Mich. 547, 563.74, 122 N.W.2d 785, 793-99 (1963) (opinion of Black and Smith, JJ., with Kavanagh and Souris, JJ., concurring) (upholding lower court injunction protecting handbilling from abridgment by shopping center).

85. Id. at 563 n.2, 122 N.W.2d at 793 n.l (1963). 
Appeals used a similar approach to uphold signature gathering on shopping center property in Sutherland $v$. Southcenter Shopping Center. ${ }^{86}$

\section{Toward an Expanded Concept of State Action Under State Constitutions}

The free speech guarantees in six state constitutions, by their terms, require some showing of governmental abridgment in order to be invoked. ${ }^{87}$ Nonetheless, in those states the principles of federalism and the requirements of an effective system of freedom of expression discussed above require that similar protections be found. As a result, courts in these states should interpret use of state trespass statutes by private owners of public forums and residential communities as state action sufficient to invoke the protection of the state constitutional guarantee of free speech. ${ }^{88}$ Although the Fourteenth Amendment does not embody this conception of state action, ${ }^{89}$

86. 3 Wash. App. 833, 846, 478 P.2d 792, 799, appeal denied, 79 Wash. 2d 1005 (1971). Both Amalgamated Clothing Workers v. Wonderland Shopping Center, 370 Mich. 547, 122 N.W.2d 785 (1963), and Sutherland v. Southcenter Shopping Center, 3 Wash. App. 833, 478 P.2d 792 (Ct. App. 1971), appeal denied, 79 Wash. 2d 1005 (1971), are also based on First Amendment reasoning that the Supreme Court has now rejected. For example, the evenly divided Michigan Supreme Court analogized the shopping center to the business block of the privately held municipality in Marsh v. Alabama, 326 U.S. 501 (1946). See 370 Mich. at 563-7I, 122 N.W.2d at 793-98. Similarly, the Washington Court of Appeals relied primarily upon Marsh v. Alabama, 326 U.S. 501 (1946), and Food Employces Local 590 v. Logan Valley Plaza, Inc., 391 U.S. 308 (1968). See 3 Wash. App. at 836-48, 478 P.2d at 794-800. The free speech guarantee of the Washington Constitution was mentioned only cursorily. Id. at 846,478 P.2d at 799. Both courts decided these cases prior to the Court's removal of the First Amendment from the private abridgment field. Such protection against private abridgment now rests exclusively upon the state constitutional guarantees of free speech as both the California, see Robins v. Pruneyard Shopping Center, 23 Cal. 3d 899, 592 P.2d 341, 153 Cal. Rptr. 854 (1979), aff'd sub nom. PruneYard Shopping Center v. Robins, 100 S. Ct. 2035 (1980), and New Jersey, see Freedman v. New Jersey State Police, 135 N.J. Super. 297, 343 A.2d 148 (1975), courts have held. Courts in California, see Robins v. Pruneyard Shopping Center, 23 Cal. 3d 899, 907-08, 592 P.2d :41, 345, 153 Cal. Rptr. 854, 858 (1979), aff'd sub nom. PruneYard Shopping Center v. Robins, 100 S. Ct. 2035 (1980), and Washington, see Sutherland v. Southcenter Shopping Center, 3 Wash. App. 833, 846, 478 P.2d 792, 799, appeal denied, 79 Wash. 2d 1005 (1971), have also construed the signature-gathering elements of the related state constitutional guarantees of initiative, referendum, and recall to protect signature gathering in shopping centers.

87. See Hawair Const. art. I, § 4; Ind. Const. art. I, § 9; Or. Const. art. I, § 8; S.C. Const. art. I, § 2; UTAH Const. art. I, \$ 15; W. VA. Const. art. III, \$ 7 .

88. The only case that has arisen thus far under the state governmental abridgment guarantees, see note 87 supra, is Lenrich Assoc. v. Heyda, 264 Or. 122, 504 P.2d 112 (1972). The Lenrich Associates court based its refusal to protect expressive activity against shop. ping center abridgment on the basis of a reading of the Fifth Amendment, id. at 127.29, 504 P.2d at 115-16, that the Supreme Court has now held to be incorrect, see PruneYard Shopping Center v. Robins, 100 S. Ct. 2035 (1980). But cf. 264 Or. at 135-37, 504 P.2d at 119 (O'Connell, C.J., dissenting) (shopping center essentially a public place, thus expressive activity therein protected under Oregon free speech guarantee).

89. See pp. 172-74 supra. 
state courts are free to use a more inclusive conception to enforce their state constitutional guarantees. ${ }^{30}$ Indeed, state courts are the most appropriate judicial institution for this task, because both the public interest in general speech $^{91}$ and individual property rights ${ }^{92}$ are defined exclusively under state law. Use of an inclusive conception of state action by these courts would insure that public forum and canvassing rights are equally protected from private as well as governmental abridgment.

\section{The Scope of State Constitutional Protection Against Private Abridgment of Speech}

Under the speech protection scheme outlined in this Note, expressive activity on all types of private property would theoretically be accorded state constitutional protection. This protection, however, should not be viewed as absolute. State constitutional protection of expressive activity against private abridgment should, like federal constitutional protection against governmental abridgment, be limited by consideration of time, place, and manner of exercise.

First Amendment doctrine in the governmental abridgment area provides an apt parallel. It is constitutional maxim that although governments may not absolutely prohibit the exercise of public forum and canvassing rights, they may subject their exercise to reasonable regulation as to time, place, and manner. ${ }^{93}$ This principle allows governments to bar absolutely expressive activity from publicly held property when that activity would be incompatible with the use to which the property was dedicated. ${ }^{94}$ Moreover, even when a person

90. See Project Report, supra note 1, at 297-301 (similar proposal).

91. A person's interest in protection of his speech against private abridgment is, like his interest in reputation, "simply one of a number which the State may protect against injury by virtue of its . . . law." Paul v. Davis, 424 U.S. 693, 712 (1976).

92. See Katz v. United States, 389 U.S. 347, 350-51 (1967) (dictum) (protection of a person's general interest in property, life, and privacy left largely to law of individual states). See also p. 178 supra.

93. See, e.g., Martin v. City of Struthers, 319 U.S. 141, 146-48 (1943) (dictum) (governments may constitutionally regulate door-to-door canvassing in order to protect privacy of individual householders and prevent criminal acts by persons posing as canvassers).

94. See Grayned v. City of Rockford, 408 U.S. 104, 116 (1972) (Court to inquire whether manner of expression is basically incompatible with normal activity of particular place). Compare Edwards v. South Carolina, 372 U.S. 229 (1963) (state precluded from preventing demonstration on state capitol grounds traditionally open to public) wilh Adderley v. Florida, 385 U.S. 39 (1966) (state could prevent demonstration on jailhouse grounds closed to public for security reasons) and Greer v. Spock, 424 U.S. 828 (1976) (military base commander may bar handbilling because it would interfere with traditional insulation of military activities from partisan political campaigns). Even the dissenters in cases refusing to protect expressive activity recognize that governments may constitutionally 
is exercising a First Amendment speech right, he may be subjected to manner and time regulations designed to prevent interference with governmental functions being performed on public property ${ }^{95}$ or with other social interests. ${ }^{96}$ Thus, nothing in the First Amendment requires either that the publicly held private office of the President be opened to expressive activity, ${ }^{97}$ or that expressive activity trample on other social interests.

A similar principle should be articulated for privately held property subject to state constitutional protection of speech. It would be premised upon federal constitutional protection of privacy in the home $^{98}$ as well as upon state constitutional limitations on rights of expression that would parallel those that exist under the First Amendment. Thus, nothing in any state constitutional guarantee of free speech would require either that the living room of a private home be opened to expressive activity, ${ }^{99}$ or that expressive activity trample on other interests of property owners.

\section{Place}

State courts should develop a test that determines in which situations private abridgment must yield to expressive activity. In a series of cases dealing with expressive activity on private property,

bar such activity from some types of publicly held property. See, e.g., Adderley v. Florida, 385 U.S. 39, 54 (1966) (Douglas, J., dissenting) (some public places may be so clearly committed to other purposes that use for expressive activity is anomalous).

95. See Cox v. Louisiana, 379 U.S. 559, 560 (1965) (government could constitutionally prohibit picketing "in or near" courthouse that had "the intent of interfering with, obstructing, or impeding the administration of justice").

96. See Martin v. City of Struthers, 319 U.S. 141, 146-48 (1943) (dictum) (governments may constitutionally regulate door-to-door canvassing in order to protect privacy of individual householders and prevent criminal acts by persons posing as canvassers).

97. This apocryphal example is found in T. EMrrson, supra note 5, at 304.

98. A number of recent Supreme Court decisions appear to cluster around a personal right of privacy in the home. The leading case is Griswold v. Connecticut, 381 U.S. 479 (1965) (marital privacy protected against statute prohibiting use of contraceptives). See Runyon v. McCrary, 427 U.S. 160, 178 (1976) (application of 42 U.S.C. $\$ 1981$ (1976) to racially discriminatory admissions policy of private school does not represent governmental intrusion into privacy of home or similarly intimate setting); Stanley v. Georgia, 394 U.S. 557, 564-66 (1969) (private possession of obscene material in one's home protected against state statute proscribing possession of obscene material). Moreover, many commentators who have urged the abolition or relaxation of the "state action" concept at the federal constitutional level contend that federally protected privacy rights will emerge as effective limitations on Fourteenth Amendment doctrine. See, e.g., Black, The Supreme Court, 1966 Term-Foreword: "State Action," Equal Protection, and California's Proposition 14, 81 HARv. L. REv. 69, 100-03 (1967).

99. This apocryphal example was discussed by Justices Powell and White in their concurrence in PruneYard Shopping Center v. Robins, 100 S. Ct. 2035, 2050-51 n.4 (1980). 
the California courts have formulated such a test. ${ }^{100}$ As explicated in In re Hoffman, ${ }^{101}$ it requires that, on properties open to the public, expressive activity be permitted as long as it does not interfere with private use of that property. ${ }^{102}$ Under this test, expressive activity may not be restricted inside a privately held shopping center, ${ }^{103}$ but may inside a company park maintained exclusively for employee use. ${ }^{104}$ Similarly, expressive activity must be permitted inside a privately held passenger railway station, ${ }^{105}$ but not in the pay parking lot of Disneyland where it interferes with the operation of the amusement park's monorail trams. ${ }^{106}$

Although this test is quite appropriate for determining when private abridgment must yield to the exercise of public forum rights, it is not appropriate for determining when it must yield to the exercise of canvassing rights, because many private properties that contain residential communities are not in fact open to the public. ${ }^{107}$

100. Although these holdings were premised upon a now discarded reading of the First Amendment, see, e.g., In re Hoffman, 67 Cal. 2d 845, 850, 434 P.2d 353, 355-56, 64 Cal. Rptr. 97, 100 (1967) (First Amendment can protect expressive activity in privately held railway station), the California Supreme Court has recently upheld them as interpretations of the state constitutional guarantee of free speech. See Robins v. Pruneyard Shopping Center, 23 Cal. 3d 899, 908-10, 592 P.2d 341, 346-47, 153 Cal. Rptr. 854, 859-60 (1979), aff'd sub nom. PruneYard Shopping Center v. Robins, 100 S. Ct. 2035 (1980).

101. 67 Cal. 2 d 845, 434 P.2d 353, 64 Cal. Rptr. 97 (1967).

102. Thus, the owners of a passenger railway station were precluded from abridging handbilling because they sought "neither privacy within nor exclusive possession of their station," id. at 851,434 P.2d at 356,64 Cal. Rptr. at 100 (station open to public for passenger railway use as well as purchases from magazine stand, restaurant, cocktail lounge and snack bar on premises, and use of waiting room, id. at 847, 434 P.2d at 354, 64 Cal. Rptr. at 98) and expressive activity "in no way interfered with the use of the station" by its owners, $i d$. at 851,434 P.2d at 357, 64 Cal. Rptr. at 101. A similar test was suggested by Justice Powell in his concurrence in Runyon v. McCrary, 427 U.S. 160, 186-89 (1976), for determining the type of private contracts proscribed by the prohibition of private racial discrimination embodied in 42 U.S.C. $\$ 1981$ (1976).

103. See Robins v. Pruneyard Shopping Center, 23 Cal. 3d 899, 592 P.2d 341, 153 Cal. Rptr. 854 (1979), aff'd sub nom. PruneYard Shopping Center v. Robins, 100 S. Ct. 2035 (1980); Sutherland v. Southcenter Shopping Center, 3 Wash. App. 833, 478 P.2d 792, appeal denied, 79 Wash. 2d 1005 (1971); Amalgamated Clothing Workers v. Wonderland Shopping Center, Inc., 370 Mich. 547, 122 N.W.2d 785 (1963) (affirming lower court by equally divided vote).

104. Cf. Good v. Dow Chemical, 247 S.W.2d 60 S (Tex. Civ. App. 1952) (claim of public access rejected because company park constituted undedicated private property).

105. See In re Hoffman, 67 Cal. 2d 845, 434 P.2d 353, 64 Cal. Rptr. 97 (1967).

106. In re Ball, 23 Cal. App. 3d 380, 100 Cal. Rptr. 189 (Ct. App. 1972).

107. The situation was aptly described by the court in State v. Kolcz, 114 N.J. Super. 408, 410, 276 A.2d 595, 596 (Middlesex County Ct. 1971): "Rossmoor [Community, described by" the court as a "planned retirement village," $i d$. at $409,276 \mathrm{~A} .2 \mathrm{~d}$ at 596] is, apparently, in part surrounded by a wall and there are gates with security guards." However, if owners of these facilities are allowed to avoid public access rights by simply closing off the premises to outsiders, the canvassing right of the expression system will be denied to significant numbers of persons. See id. at $416,276 \mathrm{~A} .2 \mathrm{~d}$ at 600 (to allow owner abridgment of canvassing would create political isolation booth). 
When canvassing rights are at issue, the Hoffman public forum test $^{108}$ should be replaced by a requirement that canvassing be permitted where a property owner exercises control over passageways connecting individual housing units. ${ }^{109}$ Any conflict between canvassing rights and the commercial and residential needs of the property owner must be balanced through time and manner regulations rather than through a wholesale abridgment of canvassing.

\section{Manner and Time}

State courts should also develop a test to determine the permissible scope of time and manner regulation by property owners required by state constitutional guarantees of free speech to permit expressive activity on their premises. First Amendment doctrine in the governmental abridgment area would provide an appropriate starting point. ${ }^{110}$

As the California ${ }^{111}$ and Washington ${ }^{112}$ courts have recognized, owners of private properties that function as public forums should be allowed to regulate expressive activity on their property in order to insure that it does not interfere with the commercial functions to which the property is dedicated. Here, the position of the public forum owner is identical to that of the government as the courthouse administrator in Cox $v$. Louisiana. ${ }^{113}$ Thus, owners might be allowed to limit expressive activity to a particular area of property. ${ }^{114}$ Owners might also be allowed to proscribe expressive activity that, although consistent with the dedicated uses of other properties, would interfere with the particular use to which their property was put. ${ }^{115}$

108. See p. 185 supra.

109. See note 60 supra (similar standard in Minnesota statute protecting canvassing rights against private abridgment).

110. See p. 184 supra.

111. Robins v. Pruneyard Shopping Center, 23 Cal. 3d 899, 911, 592 P.2d 341, 347-48, 153 Cal. Rptr. 854, 860-61 (1979), aff'd sub nom. PruneYard Shopping Center v. Robins, 100 S. Ct. 2035 (1980).

112. See Sutherland v. Southcenter Shopping Center, 3 Wash. App. 833, 847, 478 P.2d 792, 800, appeal denied, 79 Wash. 2d 1005 (1971).

113. 379 U.S. 559, 560 (1965) (government could constitutionally prohibit courthouse picketing that has intent of interfering with administration of justice).

114. A shopping center trade association has suggested that owners "might create a 'public street' or 'free-speech area' within the center complex" if no other forums were available nearby. Eagle, supra note 13, at 645 n.412 (quoting ICSC LEGAL Bull., Feb. 1973, at 1 (publication of International Council of Shopping Centers)). This was written before Hudgens v. NLRB, 424 U.S. 507 (1976), removed First Amendment considerations from this field.

115. The trial court in Lenrich Assoc. v. Heyda, Civ. No. 373-433 (Gir. Ct. Multnomah County, Or., Mar. 23, 1972), rev'd, 264 Or. 122, 504 P.2d 112 (1972), specifically proscribed noise so loud as to create a nuisance. The expressive activity in Lenrich Associates was en- 


\section{Private Abridgment}

This is consistent with the power of municipalities to protect their citizens from expressive nuisances. ${ }^{116}$ Courts should insure, however, that owners of privately held public forums do not use these powers to evade their state constitutional obligations. ${ }^{117}$

Similarly, owners of property who are required to permit canvassing on the premises should be allowed to regulate this expressive activity in order to protect the privacy ${ }^{118}$ and security ${ }^{119}$ interests of residents of the property. Thus, individual residents should be allowed to post signs that prevent canvassers from attempting to contact the residents of particular housing units, and owners should be allowed to expel canvassers who ignore these warnings. ${ }^{120}$ This privacy interest would not extend beyond the door of a particular housing unit into the privately held passageways connecting individual units, however, because a privacy interest cannot be asserted in these quasi-public passageways travelled by neighboring residents and their visitors. ${ }^{121}$

Residents and owners, however, do have a security interest in prevention of crime in the passageways and other areas of residential community, similar to the crime prevention interest shared by a municipality and its citizens. To this end, owners should be al-

gaged in by members of the International Society for Krishna Consciousness. They were also prohibited from conducting religious services, burning incense, parading, chanting, or making music. They were limited to literature distribution and discussion of their religion. See Recent Cases, supra note 75, at 1593 \& n.2.

116. See Kovacs v. Cooper, 336 U.S. 77 (1949) (upholding municipal ordinance prohibiting use of "loud and raucous" sound amplifiers).

117. The Court has consistently held that municipalities have the power to require users of their public forums to secure a permit before engaging in expressive activity therein. These requirements, however, must be administered in a nondiscriminatory manner with attention focused exclusively upon traffic control and not upon the content of any proposed activity. See Cox v. Louisiana, 379 U.S. 559 (1965); Poulos v. New Hampshire, 315 U.S. 395 (1953); Cox v. New Hampshire, 312 U.S. 569 (1941).

118. See Martin v. City of Struthers, 319 U.S. 141, 147-48 (1943) (dictum) (municipalities free to prosecute individuals who remain on householder's property after being warned away).

119. Many jurisdictions now hold apartment complex owners liable for negligence that causes their tenants to suffer criminal acts while on the premises. See, e.g., Johnston v. Harris, 387 Mich. 569, 198 N.W.2d 409 (1972).

120. See Martin v. City of Struthers, 319 U.S. 141, 147-48 (1943) (dictum) (municipalities may prosecute canvassers who ignore posted warnings).

121. In this context, the privacy interest at stake is the "right to be let alone." See Warren \& Brandeis, The Right to Privacy, 4 Hakv. L. Rev. 193, 195 (1890). This right can only be asserted inside a physical enclosure to which entry by others is absolutely barred, and is irrelevant in a setting regularly traversed by other persons. The Court has rejected other asserted privacy interests. See, e.g., Erznoznik v. City of Jacksonville, 422 U.S. 205 (1975) (privacy of passersby not invaded by observing nude scenes on quite visible drive-in theater screen); Cohen v. California, 403 U.S. 15 (1971) (privacy of passers-by not invaded by offensive insignia worn on jacket in public place); Public Utils. Comm'n v. Pollak, 343 U.S. 451 (1952) (privacy of passengers not infringed by radio played on bus). 
lowed to require canvassers to show or wear identification,122 and to register as they enter and exit the premises. ${ }^{123}$ Finally, the owner should also be allowed to insure that canvassing does not interfere with any commercial ${ }^{124}$ or institutional ${ }^{125}$ activities taking place on the premises. ${ }^{126}$

\section{Conclusion}

Cases in which state constitutional guarantees of free speech have been used to redress private abridgment, although few and not always clear, ${ }^{127}$ represent an important part of the trend away from exclusive reliance on the federal Constitution to protect civil liberties. ${ }^{128}$ These decisions will move the system of freedom of expression into a new period of federalism in which the state constitutional guarantees of free speech play a role complementary to that of the First Amendment in protecting the vital public forum and canvassing components of the system of freedom of expression.

122. See Martin v. City of Struthers, 319 U.S. 14I, 148 (1943) (dictum) (city can require canvassers to wear identification devices).

123. In Hynes v. Mayor of Oradell, 425 U.S. 610 (1976), the Court struck down as unconstitutionally vague a municipal ordinance requiring canvassers to give written notice to the local police department before canvassing. The Court stated, however, that a narrowly drawn ordinance that did not vest in municipal officials the undefined power to determine what residents will hear or see would be constitutional. Id. at 617 . A requirement that canvassers register with the owner or resident manager of the property as they enter and exit the premises would serve the owner's interest in crime prevention without hazarding the problems that rendered the ordinance in Hynes unconstitutional.

124. In Freedman v. New Jersey State Police, 135 N.J. Super. 297, 343 A.2d 148 (1975), the court held that persons granted access to an agricultural labor camp could visit its residents only during nonworking hours, because "the farmer ought not to be compelled to sit by and have his production disrupted." Id. at 302, 343 A.2d at 15I. Similarly, visitors must confine themselves to the area where the camp residents live and work. $I d$. Finally, the court held that visitors must give "reasonable notice" to the camp owner, $i d$, although it did not elaborate on the specific content of this requirement. However, the presence of commercial activity on the closed premises might justify a notice requirement that would be unnecessary in the context of a purely residential multiple housing unit community, such as an apartment complex.

125. The Minnesota canvassing statute, see note 60 supra, allows nursing home owners to deny permission to visit certain persons where valid reasons of health exist. See MiNN. STAT. ANN. $\$ 210 A .43(2)$ (c) (West Supp. 1979).

126. The owner should also be allowed to insure that canvassing is carried out in a quiet and orderly manner.

127. For example, it is unclear whether New Jersey's proscription of private abridgment of canvassing is based on common law or the free speech guarantee in the state constitution. Compare State v. Shack, 58 N.J. 297, 277 A.2d 369 (1971), with Freedman v. New Jersey State Police, 135 N.J. Super. 297, 343 A.2d 148 (1975).

128. For a good overview of state developments in a number of fields, see Project Report, supra note 1 . 